\title{
Safety of total hip arthroplasty for femoral neck fractures using the direct anterior approach: a retrospective observational study in 86 elderly patients
}

\author{
Grégoire Thürig $^{1 *}$, Jürgen Wilfried Schmitt ${ }^{1}$, Ksenija Slankamenac ${ }^{2}$ and Clément M. L. Werner ${ }^{1}$
}

\begin{abstract}
Background: The femoral neck fracture is one of the most common fractures in the elderly. A variety of methods and approaches are used to treat it. Total hip arthroplasty is a preferred approach in independent, mobile, elderly patients, given its more favorable long-term outcome.

Our hypothesis is that the direct anterior approach in geriatric trauma patients has a lower dislocation-rate with the advantage of early recovery due to a muscle sparing approach and therefore early possible full weight-bearing.

Methods: Patients were retrospectively sought who suffered a femoral neck fracture from 2008 to 2013. All patients were treated through a direct anterior approach and using the same brand of implants. Medical history, standardized physical exam, conventional pelvic plain and axial hip x-rays, Harris Hip Score, Merle D'Aubigné and Postel and SF-36 were assessed.

Results: Eighty-six patients were included in the study with a mean age of seventy-five years. The mortality rate was $16.7 \%$. Complications were encountered in nineteen patients (22.0\%) who needed operative revision and one postoperative complication (1.2\%) which could be handled conservatively. There were five intraoperative complications (5.8\%), two dislocations (2.3\%), one aseptic loosening in a non-cemented stem (1.2\%), six periprosthetic fractures in non-cemented stems (6.9\%), one displacement of a non-cemented cup (1.2\%), two early infections (2.3\%) and three hematomas (3.5\%) recorded.

Conclusions: Although the direct anterior approach is associated with a rather long learning curve we have found it to preserve the soft-tissues with no injury to abductors. It therefore shows an early advantage in elderly patients in terms of early recovery and therefore early possible full weight-bearing. Fracture treatment with dual mobility cups might lead to lower dislocation rates, but are associated with higher costs. Due to higher complication rates in non-cemented versus cemented shafts, we have changed our practice towards favoring cemented femoral stems in patients with suspected or manifest osteoporosis.
\end{abstract}

\section{Background}

The femoral neck fracture is one of the most common fractures in the elderly [1]. Younger patients are also frequently affected due to accidents. In terms of surgical treatment, there are a variety of methods for hemiarthroplasty and total arthroplasty. In ambulatory patients,

\footnotetext{
*Correspondence: g_thuerig@yahoo.de

'Departement of Traumatology, University Hospital Zurich, Rämistrasse 100, 8091 Zürich, Switzerland

Full list of author information is available at the end of the article
}

total hip replacement is the preferred treatment, given its more favorable long-term outcome [2-10]. In terms of approach - direct anterior approach [11-16], anterolateral approach $[17,18]$, lateral approach $[19$, 20], posterolateral approach [21], posterior approach [17, 22, 23], 2-incision approach [17] - the methods are often chosen independently of scientific studies and often depend on the local economic and social conditions and/or preferences of surgeons. 
The aim of this study is to review the outcome after treatment with a direct anterior approach minimal invasive total hip arthroplasty compared with the outcomes of different methods of surgical treatment of femoral neck fractures described in the literature. Our hypothesis is that the direct anterior approach in geriatric trauma patients has a lower dislocation-rate with the advantage of early recovery due to a muscle sparing approach and therefore early possible full weight-bearing.

\section{Methods}

The retrospective study was approved by the Ethical Review Board (Ref. No.: 2011-0320).

Patients were retrospectively sought who suffered a femoral neck fracture and were all operated on by two senior surgeons in the period from January 2008 to April 2013. The patients were active prior to the accident, which means they easily walked and had an active social life. Patients with prior operations on the concerning fracture side, lateral displaced neck fractures or pathological fractures, were excluded.

All patients were treated by total hip arthroplasty through a direct anterior approach under general anesthesia and were placed in a dorsal decubitus position on an extension table. Antibiotics were applied as prophylaxis before operation in all cases.

The incision was made proximal in the intermuscular plane in-between the $\mathrm{m}$. tensor fasciae latae and the $\mathrm{m}$. sartorius (super fascial layer) and $m$. rectus femoris (deep layer). The ascending branch of the arteria circumflexa femoris lateralis was ligated and dissected. The reflected tendon of the rectus femoris was released. The anterolateral joint capsule was incised in the shape of a "V". The pretrochanteric tubercle was then visible and the osteotomy of the femoral neck was done with an oscillating saw. The femoral head was extracted with a corkscrew. Now the acetabulum was fully exposed and the ligament capitis femoris was cauterized. The acetabular component was positioned after step-wise reaming. Exposure on the proximal femur was done by extension and external rotation after capsular release of the ischiofemoral and pubofemoral ligaments. The rasping and insertion of the shaft was done with precaution. If the temporary shaft was tightly positioned and stable, a cementless shaft was used, otherwise a medullary plug and cemented shaft was put in. In general a cemented shaft was chosen in patients showing poor bone quality or osteoporosis. Intraoperative control of cup and shaft positioning was always performed by fluoroscopy and adjusted as needed to assure optimal positioning. Closure was done by suturing the tensor fascia and the skin. A subcutaneus drain was only placed if acetylsalicylate was taken as medication.
The drainage was removed $24 \mathrm{~h}$ after surgery. Antibiotic prophylaxes lasted $24 \mathrm{~h}$. The patients were instructed to mobilize with full weight bearing from the first postoperative day. Conventional pelvic plain and axial hip x-rays were taken after mobilization. A thrombosis prophylaxis was applied for six weeks. Follow-up controls were after six weeks, three months, six months and at least one year after surgery.

All implants were Medacta products: all cups were Versafit and all stems were Quadra. PALACOS ${ }^{\oplus}$ bone cements were used if needed.

At time of the agreed follow-up medical history was taken and standardized physical examination was performed. Conventional pelvic plain and axial hip x-rays were taken to evaluate positioning and loosening of the implants and heterotopic ossification. No MRI has been done to investigate soft-tissue damage. Additionally, three standard questionnaires (Harris hip score, Merle D'Aubigné and Postel, SF-36) and parameters such as pain, quality of life, happiness and mobility were assessed.

Secondary outcome parameters were also recorded: intraoperative and postoperative complications (major ones which needed operative revision and minor ones which could be handled conservatively).

Statistical analyses were performed using the statistical program STATA (version 12, Stata Corp., College Station, Texas). We expressed distribution of variables using means and standard deviation (SD) for normally distributed data, and medians and interquartile ranges for non-normally distributed data. We tested data for normality with the Kolmogorow-Smirnow test and performed quantile-quantile plots of dependent variables [24].

\section{Results}

Eighty-six patients were included in the study (Table 1). The mean age was seventy-five years $(68-81)$. Sixtytwo were female $(72.1 \%)$ and twenty-four male $(27.9 \%)$.

Twenty-four (27.9\%) had already died at time of follow-up. The mortality rate was $16.7 \%$. Sixteen (18.7\%) couldn't be reached despite repeated attempts to contact both by letter and telephone. Eight (9.3 \%) didn't want to take part in the study due to medical comorbidities $(n=6)$ or personal circumstances $(n=2)$. We had a total of eighty-six $(n=86)$ with a follow-up time between zero and sixty-one months; however they were still represented in terms of complications. There were $n=65$ patients with a mean follow-up of twenty months $(12-30) \cdot n=32$ were clinically controlled and filled up the three standard questionnaires, $n=6$ were only interviewed plus filled out SF36-score.

A total of nineteen complications which needed operative revision and one postoperative complication which 
Table 1 General information about patients

\begin{tabular}{ll}
\hline & \# of patients $n=86$ \\
\hline Age (years) & $75(68-81)$ \\
Sex (male/female) & 24 / $62(27.9 \% / 72.1 \%)$ \\
Side & \\
$\quad$ - Right & $49(57 \%)$ \\
$\quad$ - Left & $37(43 \%)$ \\
Death (\%) & $24(27.9 \%)$ \\
Loss of follow up (\%) & $16(18.6 \%)$ \\
No participation (\%) & $8(9.3 \%)$ \\
Controlled & $32(37.2 \%)$ \\
Interviewed & $6(7.0 \%)$ \\
Follow up (months) & $n=65$ \\
& $20(12-30)$ \\
Mortality rate & $16 ' 744 / 100 ' 000$ \\
Patients who needed another operation (\%) & $11(12.8 \%)$ \\
Pre-operative Hb (g/L) & $127(114-135)$ \\
\hline
\end{tabular}

All results were reported as median (25th-75th percentile)

could be handled conservatively were encountered (Table 2):

None of the patients died during the operation. One patient died on the first postoperative day from circulatory failure. Another one died six days after the operation due to a complication from a secondary independent intervention for vascular-reconstruction.

There were five intraoperative fractures $(5.8 \%)$. Four non-displaced proximal femoral shaft fractures occurred while inserting the stem and made intraoperative cerclages necessary. Despite cerclage the prosthesis had no firm grip in two cases, so a cemented shaft had to be used instead. Pertrochanteric fracture occurred while inserting the stem and needed an intraoperative change to a lateral approach and plate osteosynthesis. All patients were female.
Two dislocations (2.3\%) occurred (twenty-five days and eighteen months after surgery). None of the stems were cemented or showed sign of sintering. One had a head-size of 28 and the other 32. Both of them could be treated by closed reduction and conservative management. The reason to be submitted to the hospital was because of pain after an uncontrolled movement.

The femoral component of one non-cemented arthroplasty $(1.2 \%)$ sintered in less than six weeks and needed revision due to leg length discrepancy and consecutive weakness of the abductor muscles. Despite sintering the shaft was still in a good positioning so that only the head needed to be replaced by a larger neck size.

In six cases $(6.9 \%)$ of all cementless shafts a periprosthetic fracture occurred either observed early after surgery (seven, twenty-three, twenty-nine or fifty-five days) or after several months (fourteen weeks or six months). No fractures were observed in cemented stems. Two cases needed revision by plate osteosynthesis and cerclages keeping the stem in place, two needed to be replaced by cemented shaft with additional cerclages, one case needed a total exchange of the arthroplasty with additional cerclages and autograft strut augmentation and one case needed to be replaced by cemented shaft. Two of them had signs of loosening prior to fracture. The reason for the fracture was in three cases a fall, in two cases an aseptic loosening and in one case idiopathic.

In one case $(1.2 \%)$ a displacement of the cup had to be revised fourteen days after surgery using a cemented cup.

Two patients $(2.3 \%)$ had an early infection which could both be handled by early revision by long-term antibiotics. The heads and inlays were changed along with complete capsulotomy, debridement and lavage.

Table 2 Complications

\begin{tabular}{|c|c|c|c|}
\hline Kind of complications & $n=20(23.2 \%)$ & Need for reoperation $n=19$ (22.0\%) & Way the complication was handled \\
\hline - Femoral shaft fracture & $4(4.6 \%)$ & $4(4.6 \%)$ & cerclage, cemented stem \\
\hline - Calcar fracture & $1(1.2 \%)$ & $1(1.2 \%)$ & change of approach \\
\hline - Dislocation & $2(2.3 \%)$ & $2(2.3 \%)$ & closed reduction \\
\hline - Sintering & $1(1.2 \%)$ & $1(1.2 \%)$ & larger neck size \\
\hline - Periprosthetic fracture & $6(6.9 \%)$ & $6(6.9 \%)$ & $\begin{array}{l}\text { plate osteosynthesis, cerclage, cemented } \\
\text { stem, augmentation, total exchange }\end{array}$ \\
\hline - Cup displacement & $1(1.2 \%)$ & $1(1.2 \%)$ & cemented cup \\
\hline - Infection & $2(2.3 \%)$ & $2(2.3 \%)$ & exchange of head \& inlay \\
\hline - Hematoma & $3(3.5 \%)$ & $2(2.3 \%)$ & lavage, punction \\
\hline - Thrombosis (\%) & $0(0.0 \%)$ & $0(0.0 \%)$ & - \\
\hline - Pulmonary embolism (\%) & $0(0.0 \%)$ & $0(0.0 \%)$ & - \\
\hline
\end{tabular}


Three hematomas occurred within twenty days after surgery. Two of them $(2.3 \%)$ made a revision operation necessary while one $(1.2 \%)$ could be treated by CT-guided puncture. The microbiology showed a negative result in all patients.

Treatment with low molecular weight heparin has been administered in all patients for 6 weeks. Neither a deep vein thrombosis nor a pulmonary embolism occurred after total hip arthroplasty.

Mean ranges of motion were $120^{\circ}$ for flexion, $20^{\circ}$ for internal rotation, $40^{\circ}$ for external rotation, $40^{\circ}$ for abduction and $20^{\circ}$ for adduction (Table 3 ).

The pain VAS-score was 0 , the Harris Hip Score was 94, the Merle D'Aubigné was 11, the SF-36 physical health summary score was 41.3 and mental health summary score was 51.9 and the ASA-Score showed $5.9 \%$ grade I, $43.0 \%$ grade II, $46.5 \%$ grade II and $4.6 \%$ grade IV (Tables 4 and 5).

The cup inclination angle was $44^{\circ}\left(39^{\circ}-49^{\circ}\right)$. Using the Brooker classification of ectopic ossification [25] twenty-four (27.9 \%) were diagnosed with heterotopic ossifications (Table 6).

In eight cases $(9.3 \%)$ a local sensory disturbance in the region of the scar was described, but perceived as trifling. The average leg length discrepancy was $0.16 \mathrm{~cm}$ $( \pm 0.44)$ and was always under $2 \mathrm{~cm}$.

Mean operation time was $90 \mathrm{~min}$, mean blood loss during the operation was $500 \mathrm{ml}$, needed blood-transfusion was $n=25$, number of patients who needed additional surgery due to multiple injuries was $n=11$ and mean hospitalization time was 11 days (Table 7).

\section{Discussion}

There are several studies in the literature regarding the advantage of the anterior approach of total hip arthroplasty for primary osteoarthritis, avascular necrosis of the femoral head or dysplasia [13, 15, 26-30]. But no studies described the outcome exclusively for medial femoral neck fractures in the elderly treated by this procedure.

Our intraoperative complications using the direct anterior approach were slightly higher than described in

Table 3 Range of motion

\begin{tabular}{ll}
\hline & $n=86$ \\
\hline Flexion & $120^{\circ}\left(110^{\circ}-130^{\circ}\right)$ \\
Internal rotation & $20^{\circ}\left(15^{\circ}-30^{\circ}\right)$ \\
External rotation & $40^{\circ}\left(30^{\circ}-45^{\circ}\right)$ \\
Abduction & $40^{\circ}\left(32.5^{\circ}-50^{\circ}\right)$ \\
Adduction & $20^{\circ}\left( \pm 7.5^{\circ}\right)$ \\
\hline
\end{tabular}

All results were reported as median (25th-75th percentile)
Table 4 Scores

\begin{tabular}{ll}
\hline Visual analog scale $(n=35)$ & $0(0-4)$ \\
Harris Hip Score $(n=32)$ & $94(88-99.5)$ \\
Merle d'Aubigné $(n=32)$ & $11(10.5-12)$ \\
ASA-Score $(n=86)$ & \\
$\quad$ - Grade I & $5.9 \%$ \\
- Grade II & $43.0 \%$ \\
- Grade III & $46.5 \%$ \\
- Grade IV & $4.6 \%$
\end{tabular}

All results were reported as median (25th-75th percentile)

the literature (1-5.4\%) [13, 31, 32]. However this is due to the fact that - as opposed to the results in the literature - we were not dealing with elective patients. The cause is more likely explained due to prior traumatic event, metabolic bone disorder, and that they occurred only in females.

In our study, dislocation occurred in two cases (2.3\%). This is less than what has been described in the studies $4-17.9 \%[3,10,33-37]$ and $7.6-17.2 \%$ in the metaanalyzes [5-7].

When compared to other investigators using a minimally invasive approach for femoral neck fractures, some authors seem to have a lower dislocation rate, but had either a shorter time of follow-up, did not specify which approach was used or had a younger control group [2, 38, 39].

Jacquot et al. [23] described for a modified posteropostero-lateral approach zero dislocation out of onehundred and two treated femoral neck fractures after a six weeks follow-up. It is not known if after a longer follow-up period dislocations could occur. In his study

Table 5 Scores

\begin{tabular}{lll}
\hline $\begin{array}{l}\text { SF-36 scale score } \\
(n=36)\end{array}$ & $\begin{array}{l}\text { \# of patients } n=36 \\
\text { scale score }\end{array}$ & $\begin{array}{l}\text { \# of patients } n=36 \\
\text { norm-based scale score }\end{array}$ \\
\hline Physical functioning & $57.5(29.6)$ & $39.3(12.4)$ \\
Physical Role functioning & $54.2(28.3)$ & $43.3(12.6)$ \\
Bodily Pain & $65.0(28.3)$ & $47.7(12.1)$ \\
General health perception & $58.1(18.6)$ & $44.4(8.7)$ \\
Vitality & $58.0(17.7)$ & $50.5(8.4)$ \\
Social role functioning & $83.6(18.6)$ & $49.1(9.5)$ \\
Emotional role functioning & $69.4(41.7)$ & $45.7(13.2)$ \\
Mental health & $72.8(19.0)$ & $48.6(10.8)$ \\
& $\#$ of patients $n=36$ summary score \\
Physical health summary & $41.3(10.9)$ & \\
score & & \\
Mental health summary & $51.9(10.9)$ & \\
score & &
\end{tabular}

All results were reported as mean (standard deviation) 
Table 6 Radiology

\begin{tabular}{ll}
\hline & $n=86$ \\
\hline Cup inclination & $44^{\circ}\left(39^{\circ}-49^{\circ}\right)$ \\
Heterotopic ossification & \\
Brooker's classification [33] & \\
- Grade 0 & $62(72.1 \%)$ \\
- Grade I & $19(22.1 \%)$ \\
- Grade II & $4(4.6 \%)$ \\
- Grade III & $1(1.2 \%)$ \\
- Grade IV & $0(0.0 \%)$ \\
\hline
\end{tabular}

dual mobility cups have been used as primary implants (see Table 8 for an overview related to the different approaches).

Maybe the dual mobility cup implant might be safer in terms of dislocation rate, but is associated with higher costs. In our department this type of implant is used only in revision-arthroplasty for that reason.

The cause for sintering and postoperative periprosthetic fractures (Table 2) was multifactorial. Poor bone quality due to metabolic bone disease is as well a known risk factor [40]. Marsland [41] described that $70 \%$ had, prior to a periprosthetic fracture, signs of stem loosening. Most of our patients suffered a low-energy trauma which is described to be the leading cause for postoperative periprosthetic fractures [42]. The overall incidence is about $4.1 \%$ and is higher for cementless shafts [31]. For those who suffered a femoral neck fracture, the risk to suffer a periprosthetic fracture is higher as well [40, 43, 44]. Measures like prescription of supplements and routine follow-up could have a preventive effect [41].

Superficial infection rate $(2.3 \%)$ without proof of deep infection is comparable to others. There is no publication describing an infection rate for the direct anterior approach in trauma patients. Published infection rates

Table 7 General information

\begin{tabular}{ll}
\hline & $n=86$ \\
\hline Blood loss (mL) & $500(325-600)$ \\
Postoperative transfusion (\%) & $25(29.1 \%)$ \\
$\quad$ - \# of EC & $0(0-2)$ \\
$\quad$ - min - max & $0-6$ \\
Operation time (minutes) & $90(70-110)$ \\
Antibiotics (\%) & $86(100 \%)$ \\
$\quad$ - Duration of antibiotics (hrs.) & 24 hrs \\
Length of hospital stay (days) & $11(10-14)$ \\
Rehabilitation (\%) & $48(55.8 \%)$ \\
Length of rehabilitation (days) & $21(0-21)$ \\
Other operations (\%) & $11(12.8 \%)$ \\
\hline
\end{tabular}

All results were reported as median (25th-75th percentile) for other approaches are 0-8 \% [2, 45] and a metaanalyses described an average infection rate of $3.8 \%$ [6] (Table 9).

No pulmonary embolisms or deep vein thrombosis were observed in this study. In the literature, a rate of pulmonary embolism of $0-5.8 \%[2,3,10,23,35]$ and a deep vein thrombosis rate of $0-6 \%[3,23,35]$ are described (Table 9). We guess this good result is due to early mobilization with allowed full immediate weight-bearing combined with anticoagulant-treatment in prophylactic dosage.

Patients reported a low pain VAS score. We haven't found another study using this type of score.

The mean achieved Harris Hip Score was 94 and Merle D’Aubigné score 11. This Harris Hip Score seems to be slightly better than other studies which reported a score of 75.2-93.7 [2, 3, 10, 37-39] or meta-analysis which described an average 81 [7] (Table 8). We think that this results from a muscle-sparing procedure and an early full weight-bearing.

The measured patient's functional and mental health with SF-36 showed similar results as in Baker's [33] or Macaulay's [10] studies.

Heterotopic ossification can lead to pain, muscleinsufficiency and restriction in range of motion. None of the heterotopic ossification had major restriction in range of motion. We did not use any prophylactic measures and had a better outcome than in most of the major studies regarding heterotopic ossification which reported different results.

Eggli [46] had $29.2 \%$ with grade I, $10.5 \%$ with grade II an $4.2 \%$ with grade III. He figured out that a lateral or anterolateral approach is associated with a higher rate of heterotopic ossification. Neal [47] described $43 \%$ of heterotopic ossification ( $9 \%$ severe) and concluded that heterotopic ossification are more frequent in total hip arthroplasty than believed and is a major cause of motion disability. Pavlou [48], in his retrospective study, showed an overall of $24 \%$ and found out that male sex, lateral approach, and total cemented implants are significantly associated with heterotopic ossification. Chémaly [49] reports an overall incidence of heterotopic ossification of $38 \%(n=15)$, with nine severe grade III cases regarding reconstruction of acetabular fracture through total hip replacement.

Compared to other approaches without prophylactic measures our findings showed less heterotopic ossification and thus a clear advantage. We assume that a less invasive approach leads to less traumatized tissue and, in long term, to less heterotopic ossification. Bergin et al. [50] and Meneghini et al. [51] confirmed an intermuscular approach minimizes trauma to the soft tissues. Our results need to be confirmed in a study with a larger cohort. Also a better result taking prophylactic measures 
Table 8 Comparison

\begin{tabular}{|c|c|c|c|c|c|c|c|}
\hline & Approach & $\begin{array}{l}\text { Age } \\
\text { (years) }\end{array}$ & Patients & $\begin{array}{l}\text { Follow-up } \\
\text { (months) }\end{array}$ & Dislocation (\%) & HHS & $\begin{array}{l}\text { SF-36 Mean } \\
\text { Physical/Mental }\end{array}$ \\
\hline Baker [33] & Lateral & 74 & 40 & 36 & 7.5 & & $40.53 / 52$ \\
\hline Blomfeldt [38] & Anterolateral & 81 & 60 & 12 & 0 & 87.2 & \\
\hline Dorr [34] & Posterior & 69 & 39 & 48 & 17.9 & & \\
\hline Keating [35] & Posterior/Lateral & 75 & 69 & 24 & 4 & & \\
\hline Jaquot [23] & Postero-posterolateral & 79 & 102 & 1.5 & 0 & & \\
\hline Macaulay [10] & Posterolat/Anterolateral & 82 & 17 & 24 & 5.8 & 84.2 & $40.2 / 55.7$ \\
\hline Park [3] & 2-incision & 72 & 44 & 24 & 4.5 & 88.3 & \\
\hline Mouzopoulos [39] & NS & 73 & 43 & 48 & 0 & 83.7 & \\
\hline Skinner [36] & Posterolateral & 81 & 89 & 12 & 15.7 & & \\
\hline Van den Bekerom [37] & Posterolateral/(Antero)lateral & 82 & 115 & 60 & 7 & 75.2 & \\
\hline Wani [2] & Posterolateral & 65 & 50 & 18 & 0 & 93.7 & \\
\hline Burgers [7] & Meta-Analysis & & & & 8.9 & 81 & \\
\hline Yu \& Wang [6] & Meta-Analysis & & & & 7.6 & & \\
\hline Zi-Sheng [5] & Meta-Analysis & $69-81$ & 561 & $12-156$ & 17.2 & & \\
\hline OUR & Anterior & 75 & 86 & 20 & 2.3 & 94 & $41.3 / 51.9$ \\
\hline
\end{tabular}

need to be confirmed in a study. Until then, we won't change our treatment algorithm.

The intraoperative blood loss (Table 6) is comparable to other approaches which showed an average of $385 \mathrm{ml}-$ $921 \mathrm{ml}[2,3,23]$. This might prove that the amount of blood loss is not directly related to one approach.

Hospital stay (Table 6) included waiting time until discharge to a rehabilitation facility and is handled differently from country to country. Also, some of our patients had multiple injuries and required longer hospital stays for different reasons. Other studies treating patients with femoral neck fractures described 6.8 days to 18.4 days $[2,3,10,23,37,39]$. The heterogeneous group makes it difficult to compare whether one approach leads to shorter hospitalization.

The limitations of the study include the number of patients lost to follow-up, the variety in follow-up periods and the lack of a control group. The strength of this study is that it focuses on one pathology, continuously treated with the same approach and using the same implants.

Table 9 Comparison

\begin{tabular}{|c|c|c|c|c|c|c|c|}
\hline & Approach & Infection (\%) & Thrombosis (\%) & $\begin{array}{l}\text { Pulmonary } \\
\text { embolism (\%) }\end{array}$ & $\begin{array}{l}\text { Operation } \\
\text { time (min) }\end{array}$ & Mor-tality \% & $\begin{array}{l}\text { Hospital } \\
\text { stay (days) }\end{array}$ \\
\hline Baker [33] & Lateral & 7.5 & & & & & \\
\hline Blomfeldt [38] & Anterolateral & 1.6 & & & 102 & 5 & \\
\hline Dorr [34] & Posterior & & & & & 18 & \\
\hline Keating [35] & Posterior/Lateral & 4 & 6 & 1 & 73.7 & & \\
\hline Jaquot [23] & Postero-posterolateral & 0 & 0 & 0 & 100 & & 6.8 \\
\hline Macaulay [10] & Posterolat/Anterolateral & 0 & & 5.8 & 89.1 & 23.5 & 7.7 \\
\hline Park [3] & 2-incision & 0 & 0 & 0 & 70 & & 15.1 \\
\hline Mouzopoulos [39] & NS & & & & & & 8.3 \\
\hline Skinner [36] & Posterolateral & & & & & & \\
\hline Van den Bekerom [37] & Posterolateral/(Antero)lateral & & & & & 54 & 18.4 \\
\hline Wani [2] & Posterolateral & 8 & & 2 & 100 & & 11.9 \\
\hline Burgers [7] & Meta-Analysis & & & & & 13.5 & \\
\hline Yu and Wang [6] & Meta-Analysis & & & & & & \\
\hline Zi-Sheng [5] & Meta-Analysis & 3.8 & & & & & \\
\hline OUR & Anterior & 2.3 & 0 & 0 & 90 & 16.7 & 11 \\
\hline
\end{tabular}




\section{Conclusion}

Although the direct anterior approach is associated with a rather long learning curve [52] we have found it to preserve the soft-tissues and no injury to abductors. It therefor shows an early advantage in elderly patients in terms of early recovery and therefore early possible full weight-bearing. Fracture treatment with dual mobility cups might lead to a lower dislocation rates, but are associated with higher costs. Due to higher complication rate in non-cemented versus cemented shafts we have changed our practice towards favoring cemented femoral stems in patients with suspected or manifest osteoporosis.

\section{Competing interests}

Each author certifies that he or she, or a member of their immediate family, has no commercial associations (eg, consultancies, stock ownership, equity interest, patent/licensing arrangements, etc) that might pose a conflict of interest in connection with the submitted article.

\section{Authors' contributions}

GT result interpretation, compilation of manuscript. JWS result interpretation, compilation of manuscript. SM Statistical analysis. CMLW Study conception, interpretation of results, proofreading. All authors read and approved the final manuscript.

\section{Author details}

'Departement of Traumatology, University Hospital Zurich, Rämistrasse 100, 8091 Zürich, Switzerland. ²Departement of Visceral and Transplant Surgery, University Hospital Zurich, Rämistrasse 100, 8091 Zürich, Switzerland.

Received: 7 January 2016 Accepted: 18 April 2016

Published online: 06 May 2016

\section{References}

\section{Primary Sources}

1. Johnell O, Kanis JA. An estimate of the worldwide prevalence and disability associated with osteoporotic fractures. Osteoporos Int. 2006;17(12):1726-33. doi:10.1007/s00198-006-0172-4

2. Wani IH, Sharma S, Latoo I, Salaria AQ, Farooq M, Jan M. Primary total hip arthroplasty versus internal fixation in displaced fracture of femoral neck in sexa- and septuagenarians. J Orthop Traumatol. 2014. doi:10.1007/s10195013-0278-3.

3. Park KS, Oh CS, Yoon TR. Comparison of minimally invasive total hip arthroplasty versus conventional hemiarthroplasty for displaced femoral neck fractures in active elderly patients. Chonnam Med J. 2013;49(2):81-6. doi:10.4068/cmj.2013.49.2.81.

4. Leonardsson O, Rolfson O, Hommel A, Garellick G, Akesson K, Rogmark C. Patient-reported outcome after displaced femoral neck fracture: a national survey of 4467 patients. J Bone Joint Surg Am. 2013;95(18):1693-9. doi:10.2106/JBJS.L.00836

5. Zi-Sheng A, You-Shui G, Zhi-Zhen J, Ting Y, Chang-Qing Z. Hemiarthroplasty vs primary total hip arthroplasty for displaced fractures of the femoral neck in the elderly: a meta-analysis. J Arthroplasty. 2012;27(4):583-90. doi:10.1016/j.arth.2011.07.009.

6. Yu L, Wang Y, Chen J. Total hip arthroplasty versus hemiarthroplasty for displaced femoral neck fractures: meta-analysis of randomized trials. Clin Orthop Relat Res. 2012;470(8):2235-43. doi:10.1007/s11999-012-2293-8.

7. Burgers PT, Van Geene AR, Van den Bekerom MP, Van Lieshout EM, Blom B, Aleem IS, et al. Total hip arthroplasty versus hemiarthroplasty for displaced femoral neck fractures in the healthy elderly: a meta-analysis and systematic review of randomized trials. Int Orthop. 2012;36(8):1549-60. doi:10.1007/ s00264-012-1569-7.

8. Dai Z, Li Y, Jiang D. Meta-analysis comparing arthroplasty with internal fixation for displaced femoral neck fracture in the elderly. J Surg Res. 2011;165(1):68-74. doi:10.1016/j.jss.2009.03.029.
9. Miyamoto RG, Kaplan KM, Levine BR, Egol KA, Zuckerman JD. Surgical management of hip fractures: an evidence-based review of the literature. I: femoral neck fractures. J Am Acad Orthop Surg. 2008;16(10):596-607.

10. Macaulay W, Nellans KW, lorio R, Garvin KL, Healy WL, Rosenwasser MP, et al. Total hip arthroplasty is less painful at 12 months compared with hemiarthroplasty in treatment of displaced femoral neck fracture. HSS J. 2008;4(1):48-54. doi:10.1007/s11420-007-9061-4.

11. Smith-Petersen MN. Approach to and exposure of the hip joint for mold arthroplasty. J Bone Joint Surg Am. 1949;31A(1):40-6.

12. Judet J, Judet $R$. The use of an artificial femoral head for arthroplasty of the hip joint. J Bone Joint Surg Br. 1950;32-b(2):166-73.

13. Kennon R, Keggi J, Zatorski LE, Keggi KJ. Anterior approach for total hip arthroplasty: beyond the minimally invasive technique. J Bone Joint Surg Am. 2004;86-A Suppl 2:91-7.

14. Rachbauer F. Minimally invasive total hip arthroplasty. Anterior approach. Der Orthopade. 2006;35(7):723-4, 6-9. doi:10.1007/s00132-006-0964-4.

15. Paillard P. Hip replacement by a minimal anterior approach. Int Orthop. 2007;31 Suppl 1:S13-5. doi:10.1007/s00264-007-0433-7.

16. Unger AC, Schulz AP, Paech A, Jurgens C, Renken FG. Modified direct anterior approach in minimally invasive hip hemiarthroplasty in a geriatric population: a feasibility study and description of the technique. Arch Orthop Trauma Surg. 2013;133(11):1509-16. doi:10.1007/s00402-013-1831-5.

17. Meneghini RM, Smits SA, Swinford RR, Bahamonde RE. A randomized, prospective study of 3 minimally invasive surgical approaches in total hip arthroplasty: comprehensive gait analysis. J Arthroplasty. 2008;23(6 Suppl 1):68-73. doi:10.1016/j.arth.2008.05.014.

18. Watson-Jones R. Fractures of the neck of the femur. Br J Surg. 1936;23(92): 787-808. doi:10.1002/bjs.1800239213.

19. Hardinge K. The direct lateral approach to the hip. J Bone Joint Surg. 1982;64(1):17-9.

20. Foster DE, Hunter JR. The direct lateral approach to the hip for arthroplasty. Advantages and complications. Orthopedics. 1987;10(2):274-80.

21. Wright JM, Crockett HC, Delgado S, Lyman S, Madsen M, Sculco TP. Mini-incision for total hip arthroplasty. J Arthroplasty. 2004;19(5):538-45. doi:10.1016/j.arth.2003.12.070.

22. Gibson A. Posterior exposure of the hip joint. J Bone Joint Surg. 1950;32-B(2):183-6.

23. Jacquot F, Ait Mokhtar M, Sautet A, Doursounian L, Masquelet AC, Feron JM The mini postero-postero-lateral mini incision in total hip arthroplasty. Int Orthop. 2013;37(10):1891-5. doi:10.1007/s00264-013-1970-x.

24. Vardeman S, Chambers J, Cleveland W, Kleiner B, Tukey P. Graphical methods for data-analysis. J Qual Technol. 1984;16(3):177-8.

25. Brooker AF, Bowerman JW, Robinson RA, Riley Jr LH. Ectopic ossification following total hip replacement. Incidence and a method of classification. J Bone Joint Surg Am. 1973;55(8):1629-32.

26. Maffiuletti NA, Impellizzeri FM, Widler K, Bizzini M, Kain MS, Munzinger U, et al. Spatiotemporal parameters of gait after total hip replacement: anterior versus posterior approach. Orthop Clin North Am. 2009;40(3):407-15. doi:10.1016/j.ocl.2009.02.004.

27. Mayr E, Nogler M, Benedetti MG, Kessler O, Reinthaler A, Krismer M, et al. A prospective randomized assessment of earlier functional recovery in THA patients treated by minimally invasive direct anterior approach: a gait analysis study. Clin Biomech. 2009;24(10):812-8. doi:10.1016/j.clinbiomech.2009.07.010.

28. Matta JM, Shahrdar C, Ferguson T. Single-incision anterior approach for total hip arthroplasty on an orthopaedic table. Clin Orthop Relat Res. 2005;441:115-24.

29. Bhandari M, Matta JM, Dodgin D, Clark C, Kregor P, Bradley G, et al. Outcomes following the single-incision anterior approach to total hip arthroplasty: a multicenter observational study. Orthop Clin North Am. 2009;40(3):329-42. doi:10.1016/j.ocl.2009.03.001.

30. Siguier T, Siguier M, Brumpt B. Mini-incision anterior approach does not increase dislocation rate: a study of 1037 total hip replacements. Clin Orthop Relat Res. 2004;426:164-73.

31. Berry DJ. Epidemiology: hip and knee. Orthop Clin North Am. 1999;30(2):183-90.

32. De Geest T, Vansintjan P, De Loore G. Direct anterior total hip arthroplasty: complications and early outcome in a series of 300 cases. Acta Orthop Belg. 2013;79(2):166-73.

33. Baker RP, Squires B, Gargan MF, Bannister GC. Total hip arthroplasty and hemiarthroplasty in mobile, independent patients with a displaced intracapsular fracture of the femoral neck. A randomized, controlled trial. J Bone Joint Surg Am. 2006;88(12):2583-9. doi:10.2106/jbjs.e.01373. 
34. Dorr LD, Maheshwari AV, Long WT, Wan Z, Sirianni LE. Early pain relief and function after posterior minimally invasive and conventional total hip arthroplasty. A prospective, randomized, blinded study. J Bone Joint Surg Am. 2007:89(6):1153-60. doi:10.2106/JBJS.F.00940.

35. Keating JF, Grant A, Masson M, Scott NW, Forbes JF. Randomized comparison of reduction and fixation, bipolar hemiarthroplasty, and total hip arthroplasty. Treatment of displaced intracapsular hip fractures in healthy older patients. J Bone Joint Surg Am. 2006;88(2):249-60. doi:10.2106/jbjs.e.00215.

36. Skinner P, Riley D, Ellery J, Beaumont A, Coumine R, Shafighian B. Displaced subcapital fractures of the femur: a prospective randomized comparison of internal fixation, hemiarthroplasty and total hip replacement. Injury. 1989;20(5):291-3.

37. van den Bekerom MP, Hilverdink EF, Sierevelt IN, Reuling EM, Schnater JM, Bonke $\mathrm{H}$, et al. A comparison of hemiarthroplasty with total hip replacement for displaced intracapsular fracture of the femoral neck: a randomised controlled multicentre trial in patients aged 70 years and over. J Bone Joint Surg. 2010;92(10):1422-8. doi:10.1302/0301-620x.92b10.24899.

38. Blomfeldt R, Tornkvist H, Eriksson K, Soderqvist A, Ponzer S, Tidermark J. A randomised controlled trial comparing bipolar hemiarthroplasty with total hip replacement for displaced intracapsular fractures of the femoral neck in elderly patients. J Bone Joint Surg. 2007:89(2):160-5. doi:10.1302/0301-620x. $89 \mathrm{~b} 2.18576$

39. Mouzopoulos G, Stamatakos M, Arabatzi H, Vasiliadis G, Batanis G, Tsembeli A, et al. The four-year functional result after a displaced subcapital hip fracture treated with three different surgical options. Int Orthop. 2008;32(3):367-73. doi:10.1007/s00264-007-0321-1.

40. Franklin J, Malchau H. Risk factors for periprosthetic femoral fracture. Injury. 2007;38(6):655-60. doi:10.1016/j.injury.2007.02.049.

41. Marsland D, Mears SC. A review of periprosthetic femoral fractures associated with total hip arthroplasty. Geriatr Orthop Surg Rehabil. 2012:3(3):107-20. doi:10.1177/2151458512462870.

42. Zuurmond RG, van Wijhe W, van Raay JJ, Bulstra SK. High incidence of complications and poor clinical outcome in the operative treatment of periprosthetic femoral fractures: An analysis of 71 cases. Injury. 2010:41(6):629-33. doi:10.1016/j.injury.2010.01.102.

43. Sarvilinna R, Huhtala HS, Sovelius RT, Halonen PJ, Nevalainen JK, Pajamaki KJ. Factors predisposing to periprosthetic fracture after hip arthroplasty: a case ( $n=31)$-control study. Acta Orthop Scand. 2004;75(1):16-20. doi:10.1080/ 00016470410001708030.

44. Lindahl H, Malchau H, Herberts P, Garellick G. Periprosthetic femoral fractures classification and demographics of 1049 periprosthetic femoral fractures from the Swedish National Hip Arthroplasty Register. J Arthroplasty. 2005;20(7):857-65. doi:10.1016/j.arth.2005.02.001.

45. Christensen CP, Karthikeyan T, Jacobs CA. Greater prevalence of wound complications requiring reoperation with direct anterior approach total hip arthroplasty. J Arthroplasty. 2014. doi:10.1016/j.arth.2014.04.036.

46. Eggli S, Woo A. Risk factors for heterotopic ossification in total hip arthroplasty. Arch Orthop Trauma Surg. 2001;121(9):531-5.

47. Neal B, Gray H, MacMahon S, Dunn L. Incidence of heterotopic bone formation after major hip surgery. ANZ J Surg. 2002;72(11):808-21.

48. Pavlou G, Salhab M, Murugesan L, Jallad S, Petsatodis G, West R, et al. Risk factors for heterotopic ossification in primary total hip arthroplasty. Hip Int. 2012;22(1):50-5. doi:10.5301/hip.2012.9057.

49. Chemaly O, Hebert-Davies J, Rouleau DM, Benoit B, Laflamme GY. Heterotopic ossification following total hip replacement for acetabular fractures. Bone Joint J. 2013;95-b(1):95-100. doi:10.1302/0301-620x.95b1.29721

50. Bergin PF, Doppelt JD, Kephart CJ, Benke MT, Graeter JH, Holmes AS, et al. Comparison of minimally invasive direct anterior versus posterior total hip arthroplasty based on inflammation and muscle damage markers. J Bone Joint Surg Am. 2011;93(15):1392-8. doi:10.2106/jbjs.j.00557.

51. Meneghini RM, Pagnano MW, Trousdale RT, Hozack WJ. Muscle damage during MIS total hip arthroplasty: Smith-Petersen versus posterior approach. Clin Orthop Relat Res. 2006:453:293-8. doi:10.1097/01.blo.0000238859.46615.34.

52. Muller DA, Zingg PO, Dora C. Anterior minimally invasive approach for total hip replacement: five-year survivorship and learning curve. Hip Int. 2014;24(3):277-83. doi:10.5301/hipint.5000108.

\section{Submit your next manuscript to BioMed Central and we will help you at every step:}

- We accept pre-submission inquiries

- Our selector tool helps you to find the most relevant journal

- We provide round the clock customer support

- Convenient online submission

- Thorough peer review

- Inclusion in PubMed and all major indexing services

- Maximum visibility for your research

Submit your manuscript at www.biomedcentral.com/submit 